\title{
Combination therapy for hypertension in the elderly: a sub-analysis of the Combination Therapy of Hypertension to Prevent Cardiovascular Events (COPE) Trial
}

\author{
Toshio Ogihara ${ }^{1,2}$, Masunori Matsuzaki ${ }^{3}$, Seiji Umemoto ${ }^{4}$, Hiromi Rakugi ${ }^{1}$, Hiroaki Matsuoka ${ }^{5}$, \\ Kazuyuki Shimada $^{6}$, Jitsuo Higaki ${ }^{7}$, Sadayoshi Ito ${ }^{8}$, Akira Kamiya ${ }^{4}$, Hiromichi Suzuki ${ }^{9}$, Yasuo Ohashi ${ }^{10}$, \\ Kazuaki Shimamoto ${ }^{11}$ and Takao Saruta ${ }^{12}$, for the Combination Therapy of Hypertension to Prevent \\ Cardiovascular Events Trial Group
}

The Combination Therapy of Hypertension to Prevent Cardiovascular Events (COPE) trial demonstrated that the calcium-channel blocker benidipine-based combination therapies with an angiotensin-receptor blocker (ARB), a $\beta$-blocker, or a thiazide diuretic (thiazide) were similarly effective in preventing cardiovascular events and achieving the target blood pressure (BP; $<140 /$ $90 \mathrm{~mm} \mathrm{Hg}$ ). We further evaluated the efficacy and safety of these combination therapies in older ( $\geqslant 65$ years) and younger ( $<65$ years) hypertensive patients. In this sub-analysis of the COPE trial 3293 patients $(1533 \geqslant 65$ years old and $1760<65$ years old) were randomly assigned to receive benidipine-based therapy with an ARB, a $\beta$-blocker or a thiazide. In each group, the average BP did not differ among the three treatment groups. The incidence of the primary cardiovascular composite end point in the older group was higher than in the younger group (12.7 vs. 8.3 per 1000 person-years, $P=0.023$ ). The primary composite cardiovascular end point, achievement (\%) of target $\mathrm{BP}$, and cardiovascular hard composite end points were similar among the three treatment groups. However, the hazard ratios and 95\% confidence intervals in older patients were 2.74 (1.08-6.96; $\beta$-blocker vs. thiazide, $P=0.022)$ for fatal and non-fatal stroke, and 2.47 (1.03-5.91; $\beta$-blocker vs. ARB, $P=0.043)$ for newonset diabetes. Thus, benidipine combined with an ARB, a $\beta$-blocker, or a thiazide was similarly effective in preventing cardiovascular events and achieving the target BP in both older and younger hypertensive patients. Further studies will be necessary to evaluate the usefulness of benidipine combined with a $\beta$-blocker in terms of the incidence of stroke and new-onset diabetes in older patients.

Hypertension Research (2012) 35, 441-448; doi:10.1038/hr.2011.216; published online 26 January 2012

Keywords: angiotensin-receptor blocker; $\beta$-blocker; calcium-channel blocker; elderly; thiazide diuretic

\section{INTRODUCTION}

It is well established that antihypertensive treatment reduces cardiovascular morbidity and mortality even in elderly patients with hypertension. ${ }^{1-3}$ Recently, the Hypertension in the Very Elderly Trial (HYVET) documented the efficacy of antihypertensive therapy to reduce cardiovascular mortality in hypertensive patients aged $\geqslant 80{ }^{4}$ Many guidelines for management of hypertension, including the Japanese Society guideline, recommend tight blood pressure (BP) control to $<140 / 90 \mathrm{~mm} \mathrm{Hg}^{1-3}$
It is well-known that the majority of hypertensive patients will require at least two antihypertensive drugs to reach the target $\mathrm{BP}^{1-3}$ Benidipine is a potent and long-acting dihydropyridine calciumchannel blocker (CCB), which inhibits not only L-type and N-type calcium channels but also T-type calcium channels, and regulates the constriction and dilation of renal efferent arterioles. ${ }^{5}$ The Combination Therapy of Hypertension to Prevent Cardiovascular Events (COPE) trial is a prospective, randomized, open-label, blinded-endpoint (PROBE) study to determine the optimal combination of CCB

\footnotetext{
${ }^{1}$ Department of Geriatric Medicine and Nephrology, Osaka University Graduate School of Medicine, Suita, Japan; ${ }^{2}$ Morinomiya University of Medical Sciences, Osaka, Japan; ${ }^{3}$ Department of Medicine and Clinical Science, Yamaguchi University Graduate School of Medicine, Ube, Japan; ${ }^{4}$ Pharmaceutical Clinical Research Center, Yamaguchi University Hospital, Ube, Japan; ${ }^{5}$ Department of Hypertension and Cardiorenal Medicine, Dokkyo Medical University, Mibu, Japan; ${ }^{6}$ Division of Cardiovascular Medicine, Department of Medicine, Jichi Medical University School of Medicine, Shimotsuke, Japan; ${ }^{7}$ Division of Cardiology, Department of Integrated Medicine and Informatics, Ehime University Graduate School of Medicine, Toon, Japan; ${ }^{8}$ Division of Nephrology, Endocrinology and Vascular Medicine, Department of Medicine, Tohoku University School of Medicine, Sendai, Japan; ${ }^{9}$ Department of Nephrology, Saitama Medical University School of Medicine, Iruma, Japan; ${ }^{10}$ Departement of Biostatistics, School of Public Health, University of Tokyo, Tokyo, Japan; ${ }^{11}$ Sapporo Medical University School of Medicine, Sapporo, Japan and ${ }^{12 K e i o ~ U n i v e r s i t y, ~ T o k y o, ~ J a p a n ~}$

Correspondence: Associate Professor S Umemoto, Pharmaceutical Clinical Research Center, Yamaguchi University Hospital, 1-1-1 Minami-Kogushi, Ube, Yamaguchi 755-8505, Japan. E-mail: umemoto@yamaguchi-u.ac.jp
}

Received 19 September 2011; accepted 5 October 2011; published online 26 January 2012 
benidipine-based therapy for hypertension, ${ }^{6,7}$ and the main results have demonstrated that the percentage of subjects achieving the target BP and the incidence of primary composite cardiovascular end points were similar among benidipine-thiazide diuretic (thiazide), benidipine-angiotensin-receptor blocker (ARB) and benidipine- $\beta$-blocker subgroups. However, second analyses suggested that benidipine combined with a $\beta$-blocker appeared to be less beneficial in reducing the risk of stroke compared with the benidipine-thiazide combination, and was associated with an increased incidence of new-onset diabetes compared with the benidipine-ARB combination.

It remains unknown which combination therapy is valuable for achieving the target BP and preventing the occurrence of cardiovascular events during treatment for hypertension in the elderly, although tight $\mathrm{BP}$ control to $<140 / 90 \mathrm{~mm} \mathrm{Hg}$ is recommended for the elderly. ${ }^{1-3}$ Thus, in this sub-analysis of the COPE trial, we aimed to determine which combination was useful to achieve the target $\mathrm{BP}$ and prevent the occurrence of cardiovascular events in hypertensive patients $\geqslant 65$ years old.

\section{METHODS}

\section{Study design, setting and participants}

The COPE trial was an investigator-initiated multi-center study with PROBE design that compared cardiovascular effects and achievement of target BP $(<140 / 90 \mathrm{~mm} \mathrm{Hg})$ with three dihydropyridine CCB benidipine-based regimens (ARB, $\beta$-blocker or thiazide) in 3501 hypertensive patients who did not achieve the target $\mathrm{BP}$ with benidipine $4 \mathrm{mg}$ per day. ${ }^{6,7}$

The rationale and design, trial management, and the main results of the COPE trial have already been reported. ${ }^{6,7}$ In brief, participants with a sitting systolic BP of $\geqslant 140 \mathrm{~mm} \mathrm{Hg}$ or a diastolic BP of $\geqslant 90 \mathrm{~mm} \mathrm{Hg}$, or both if untreated, or whatever the treatment, were men and women aged 40-85 years who did not achieve the target $\mathrm{BP}(<140 / 90 \mathrm{~mm} \mathrm{Hg})$ with a sitting position at clinic with monotherapy of benidipine $4 \mathrm{mg}$ per day in the run-in phase (4-8 weeks). These patients were randomly assigned to receive benidipine combined with an ARB, a $\beta$-blocker or a thiazide. After the randomization, all patients were followed-up for at least 3 years until the trial was terminated. The BP management titration algorithm, together with other details on the study design, were as described previously. ${ }^{6,7}$ At each follow-up visit, we obtained information about any suspected composite end point or adverse event. The median follow-up was 3.6 years. ${ }^{7}$

\section{Outcome measures}

A pre-specified post-hoc analysis was made to compare the cardiovascular effects of benidipine-based combination regimens (benidipine-ARB vs. benidipine- $\beta$-blocker $v$ s. benidipine-thiazide) in older ( $\geqslant 65$ years old) and younger patients ( $<65$ years old). The evaluated end points were consistent with the original trial design and included the primary and secondary end points of the COPE trial: ${ }^{6}$ co-primary end points; composite of cardiovascular morbidity and mortality (sudden death, fatal or non-fatal stroke, fatal or non-fatal myocardial infarction, hospitalization due to unstable angina, new onset of heart failure (New York Heart Association class II-IV), new onset or worsening of peripheral arterial disease, and renal events defined as serum creatinine level doubled to over $2 \mathrm{mg} \mathrm{dL}^{-1}$, serum creatinine $\geqslant 4.0 \mathrm{mg} \mathrm{dL}^{-1}$, or renal dialysis), and achievement of target BP $(<140 / 90 \mathrm{~mm} \mathrm{Hg})$; and secondary end points: all-cause mortality, hard composite cardiovascular events (cardiovascular death, non-fatal myocardial infarction and non-fatal stroke excluding transient ischemic attack), new onset of diabetes and adverse events.

\section{Statistical methods}

In total, 3293 patients (1110, benidipine-ARB; 1089 , benidipine- $\beta$-blocker; and 1094, benidipine-thiazide) who were prescribed a combination treatment were compared in the two groups with full-set analysis to specifically evaluate benidipine-based combination therapy for elderly hypertension in the COPE trial. $^{7}$ Patient characteristics were reported as mean \pm s.d. or percentage. Continuous variables were compared with Student's $t$ tests or one-way analysis of variance, as appropriate. Categorical variables were compared with $\chi^{2}$ test. In one of the primary analyses, the proportion of patients who achieved the target BP was compared using $\chi^{2}$ test between the treatment groups. Survival curves were generated by the Kaplan-Meier method for the primary cardiovascular composite end point and secondary end points among three treatment groups. Survival curves were compared using log-rank test. Confidence intervals (CIs) were calculated using Cox proportional hazards model. The proportion of patients who reported adverse events was also compared using $\chi^{2}$ test. All data were analyzed using SAS System Release 9.1 (SAS Institute, Cary, NC, USA). All reported $P$ values are two-sided.

\section{RESULTS}

Demographic and baseline patient characteristics of the COPE trial are shown in Table 1. Among the 3293 patients in the COPE trial, 1533 patients $(46.6 \%)$ were $\geqslant 65$ years old and 1760 patients $(53.4 \%)$ were $<65$ years old. In both age groups, baseline characteristics were well matched among those randomized to the three regimens.

At baseline, the mean age of the older group was 72.6 years and the younger group was 54.7 years. Systolic BP in the older group was higher at baseline (mean: $155 \pm 11 \mathrm{~mm} \mathrm{Hg}$ in the older group and $153 \pm 12 \mathrm{~mm} \mathrm{Hg}$ in the younger group), the older group had lower diastolic BP $(85 \pm 9$ vs. $92 \pm 9 \mathrm{~mm} \mathrm{Hg})$ and hence wider pulse pressures. The older group had higher rates of previous cardiovascular disease $(18.3$ vs. $7.1 \%)$, which were mainly stroke $(4.4 \%$ vs. $1.0 \%)$ and angina pectoris $(4.8 \%$ vs. $1.1 \%)$; had higher rate of prescription of antihypertensive agents ( $84.5 \%$ vs. $76.0 \%)$; had higher rate of diabetes ( $16.6 \%$ vs. $12.1 \%)$ and dyslipidemia $(43.1 \%$ vs. $36.6 \%)$; reported taking more prophylactic antiplatelet agents $(12.0 \%$ vs. $3.9 \%)$, statin as lipid-lowering agents $(21.7 \%$ vs. $12.4 \%)$, and antidiabetic agents ( $8.9 \%$ vs. $5.6 \%)$, than those $<65$ years. Younger patients had slightly higher body-mass index $\left(25.0 \pm 3.5\right.$ vs. $\left.24.0 \pm 3.2 \mathrm{~kg} \mathrm{~m}^{-2}\right)$ and were more likely to be current smokers $(46.8 \%$ vs. $31.2 \%)$ than those aged $\geqslant 65$ years.

\section{Blood pressure}

The reduction in BP from baseline was similar among the three treatment groups in both age groups over the course of the trial. At the end of the treatment phase, mean average BP in the younger group and older group was $134 \pm 15 / 80 \pm 10 \mathrm{~mm} \mathrm{Hg}$ and $135 \pm 15$ / $74 \pm 10 \mathrm{~mm} \mathrm{Hg}$, respectively. Table 2 shows means of BP at the end of the treatment phase and proportion of patients achieving target BP among patients aged $\geqslant 65$ years and patients aged $<65$ years. Diastolic BP in the older group was significantly lower than that in the younger group, whereas systolic BP did not differ between the two age groups. Average BP did not differ among the three treatment groups in each age group (Table 2). At the end of treatment, the percentage of patients who achieved the target BP did not differ among the three treatment groups in each age group nor between the two age groups.

\section{Cardiovascular outcomes}

Table 3 shows the incidence of primary cardiovascular composite end point and secondary end points in the benidipine-ARB, benidipine- $\beta$-blocker, and benidipine-thiazide groups, respectively. The incidence of primary cardiovascular composite end point in the older group was higher than in the younger group (12.7 vs. 8.3 per 1000 person-years).

Figure 1 shows the survival curves for time to first primary cardiovascular composite end points in the younger and older groups. Although compared with the benidipine-thiazide group, the hazard ratio was higher in the benidipine-ARB and benidipine- $\beta$-blocker 
Table 1 Demographic and baseline characteristics of the study patients

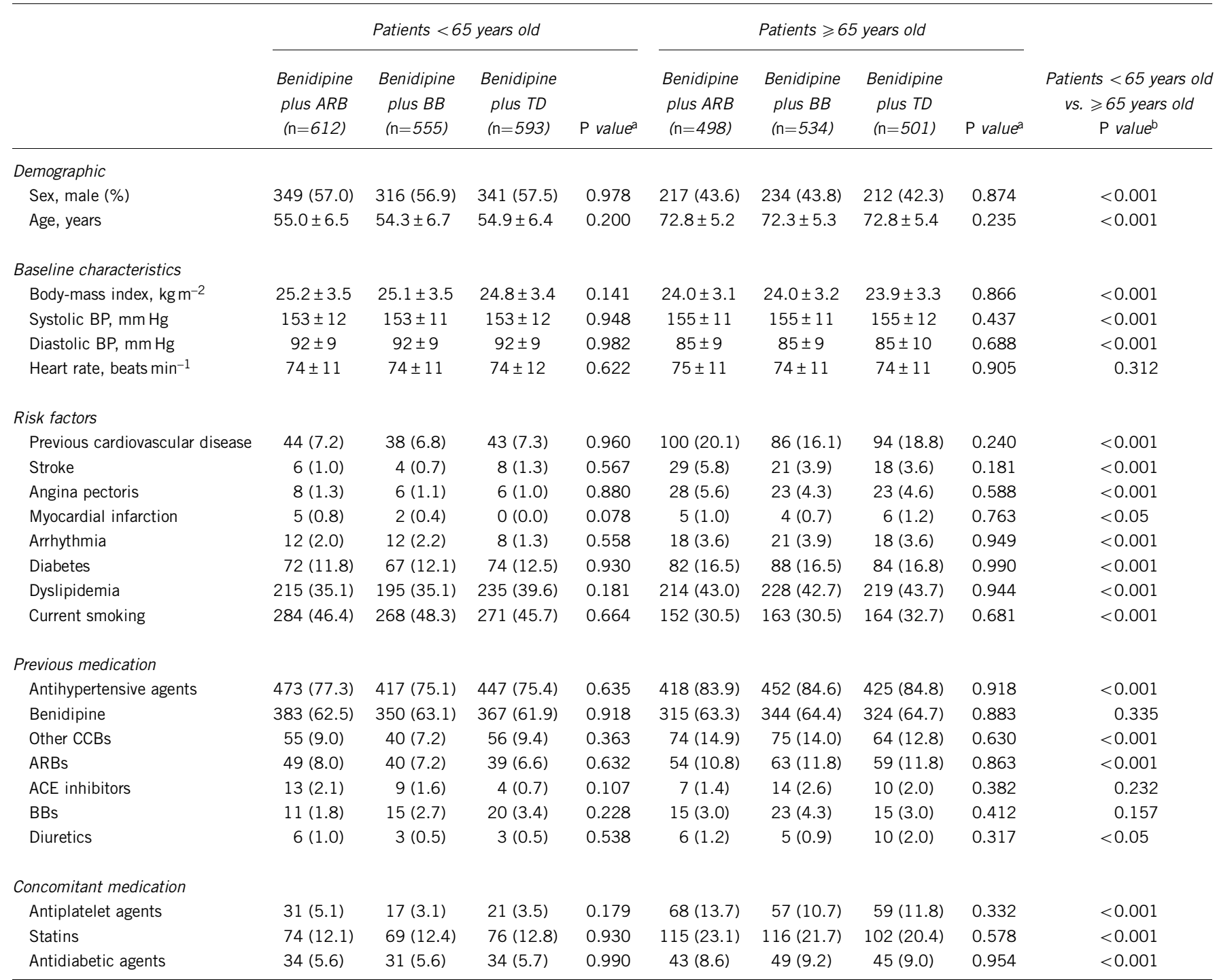

Abbreviations: ACE, angiotensin-converting enzyme; ARB, angiotensin receptor blocker; BB, $\beta$-blocker; BP, blood pressure; CCB, calcium channel blocker; TD, thiazide diuretic.

Data are shown as number of patients $(\%)$ or mean \pm s.d.

aDifferences in proportions among the three groups were analyzed using $\chi^{2}$ test and in means among the three groups were analyzed using one-way analysis of variance.

${ }^{b}$ Differences in proportions between patients $<65$ years old and patients $\geqslant 65$ years old were compared using $\chi^{2}$ test and in means between the two groups were compared using Student's $t$ tests.

groups of the younger group, and compared with the benidipinethiazide or ARB groups, the hazard ratio was higher in the benidipine$\beta$-blocker group of the older group, the difference in the incidence of the primary cardiovascular composite end point among the three treatment groups did not reach statistical significance.

As for secondary end points (Table 3 ), the incidence of cardiovascular hard composite end points was higher in the older group than in the younger group (7.5 vs. 4.3 per 1000 person-years). As shown in Figure 2, although compared with the benidipine-thiazide group, the hazard ratio was higher in the benidipine-ARB and benidipine- $\beta$ blocker groups of the younger group, the incidence of the cardiovascular hard composite end points did not differ among the three treatment groups of the younger and older groups, respectively. Figure 3 shows the survival curves for time to first fatal and nonfatal strokes in the two age groups. The hazard ratio of fatal and nonfatal strokes was significantly higher in the benidipine- $\beta$-blocker group than in the benidipine-thiazide group of the older group, whereas it did not differ among the three treatment groups of the younger group (Figure 3), although the incidence of fatal and non-fatal stroke was not different between the younger and older groups (Table 3). The incidence of all-cause mortality was higher in the older group than in the younger group (10.1 vs. 2.4 per 1000 person-years) as shown in Table 3, whereas the incidence of all-cause mortality was not different among the three treatment groups of the two age groups (Figure 2). In addition, compared with the benidipine-ARB group, the hazard ratio of the incidence of new-onset diabetes was significantly higher in the benidipine- $\beta$-blocker group of only the older group, whereas it did not differ among the three treatment groups of the younger group (Figure 2), although the incidence of new-onset diabetes was not different between the two age groups.

\section{Safety}

Table 4 shows the adverse events reported in the COPE trial. Overall, older patients reported more adverse events than younger patients. 
Table 2 Effects of treatment on mean systolic and diastolic BP and proportions of target BP at the end of the treatment phase in patients at least 65 years old and patients below 65 years old

\begin{tabular}{|c|c|c|c|c|c|c|c|c|c|}
\hline & \multicolumn{4}{|c|}{ Patients $<65$ years old } & \multicolumn{4}{|c|}{ Patients $\geqslant 65$ years old } & \multirow[b]{2}{*}{$\begin{array}{c}\text { Patients }<65 \text { years old } \\
\text { vs. } \geqslant 65 \text { years old } \\
\mathrm{P} \text { value }\end{array}$} \\
\hline & $\begin{array}{c}\text { Benidipine } \\
\text { plus } A R B \\
(\mathrm{n}=612)\end{array}$ & $\begin{array}{l}\text { Benidipine } \\
\text { plus } B B \\
(\mathrm{n}=555)\end{array}$ & $\begin{array}{l}\text { Benidipine } \\
\text { plus TD } \\
(\mathrm{n}=593)\end{array}$ & $\mathrm{P}$ value & $\begin{array}{l}\text { Benidipine } \\
\text { plus } A R B \\
(\mathrm{n}=498)\end{array}$ & $\begin{array}{l}\text { Benidipine } \\
\text { plus } B B \\
(\mathrm{n}=534)\end{array}$ & $\begin{array}{l}\text { Benidipine } \\
\text { plus TD } \\
(\mathrm{n}=501)\end{array}$ & $\mathrm{P}$ value $\mathrm{a}^{\mathrm{a}}$ & \\
\hline Systolic BP & $134 \pm 15$ & $133 \pm 15$ & $134 \pm 14$ & 0.629 & $135 \pm 16$ & $134 \pm 15$ & $134 \pm 15$ & 0.391 & 0.243 \\
\hline Diastolic BP & $80 \pm 10$ & $80 \pm 10$ & $80 \pm 10$ & 0.885 & $74 \pm 10$ & $74 \pm 10$ & $73 \pm 10$ & 0.447 & $<0.001$ \\
\hline Proportions of patients achieving target BP & 63.1 & 66.6 & 64.3 & 0.526 & 65.4 & 67.1 & 67.8 & 0.738 & 0.232 \\
\hline
\end{tabular}

Abbreviations: ARB, angiotensin receptor blocker; BB, $\beta$-blocker; BP, blood pressure; TD, thiazide diuretic.

Data of the proportions of target blood pressure are shown as percentage of patients (\%) or mean \pm SD. Target BP of the COPE trial: $<140 / 90 \mathrm{~mm} \mathrm{Hg}$.

aDifferences in proportions among the three treatment groups were analyzed using $\gamma^{2}$ test and in means among the three treatment groups were analyzed using one-way analysis of variance.

bDifferences in proportions between patients $<65$ years old and patients $\geqslant 65$ years old were compared using $\chi^{2}$ test and in means between the two age groups were compared using Student's $t$ tests.

Table 3 Incidence of primary and secondary end points among patients at least 65 years old and patients below 65 years old

\begin{tabular}{|c|c|c|c|c|c|c|c|c|c|}
\hline & \multicolumn{4}{|c|}{ Patients $<65$ years old } & \multicolumn{4}{|c|}{ Patients $\geqslant 65$ years old } & \multirow[b]{2}{*}{$\begin{array}{c}\text { Patients }<65 \text { years old } \\
\text { vs. } \geqslant 65 \text { years old } \\
\mathrm{P} \text { value }\end{array}$} \\
\hline & $\begin{array}{c}\text { Benidipine } \\
\text { plus } A R B \\
(\mathrm{n}=612)\end{array}$ & $\begin{array}{l}\text { Benidipine } \\
\text { plus } B B \\
(\mathrm{n}=555)\end{array}$ & $\begin{array}{l}\text { Benidipine } \\
\text { plus TD } \\
(\mathrm{n}=593)\end{array}$ & $\mathrm{P}$ value & $\begin{array}{c}\text { Benidipine } \\
\text { plus } A R B \\
(\mathrm{n}=498)\end{array}$ & $\begin{array}{l}\text { Benidipine } \\
\text { plus } B B \\
(\mathrm{n}=534)\end{array}$ & $\begin{array}{l}\text { Benidipine } \\
\text { plus TD } \\
(\mathrm{n}=501)\end{array}$ & $\mathrm{P}$ value & \\
\hline \multicolumn{10}{|l|}{ Primary end points } \\
\hline Incidence number & 20 & 19 & 13 & & 21 & 29 & 19 & & \\
\hline Per 1000 person-years & 9.2 & 9.8 & 6.2 & 0.399 & 11.8 & 15.6 & 10.6 & 0.374 & 0.023 \\
\hline \multicolumn{10}{|c|}{ Secondary end points } \\
\hline \multicolumn{10}{|c|}{ Cardiovascular hard composite end points } \\
\hline Incidence number & 12 & 11 & 4 & & 13 & 18 & 10 & & \\
\hline Per 1000 person-years & 5.4 & 5.6 & 1.9 & 0.115 & 7.3 & 9.6 & 5.5 & 0.358 & 0.025 \\
\hline \multicolumn{10}{|l|}{ Fatal and non-fatal stroke } \\
\hline Incidence number & 8 & 10 & 6 & & 9 & 17 & 6 & & \\
\hline Per 1000 person-years & 3.6 & 5.1 & 2.8 & 0.492 & 5.0 & 9.0 & 3.3 & 0.064 & 0.119 \\
\hline \multicolumn{10}{|l|}{ All-cause mortality } \\
\hline Incidence number & 5 & 2 & 8 & & 20 & 21 & 15 & & \\
\hline Per 1000 person-years & 2.2 & 1.0 & 3.7 & 0.195 & 11.1 & 11.0 & 8.2 & 0.611 & $<0.001$ \\
\hline \multicolumn{10}{|l|}{ New-onset diabetes } \\
\hline Incidence number & 14 & 19 & 17 & & 7 & 18 & 15 & & \\
\hline Per 1000 person-years & 6.4 & 9.8 & 8.1 & 0.464 & 3.9 & 9.6 & 8.4 & 0.106 & 0.651 \\
\hline
\end{tabular}

Abbreviations: ARB, angiotensin receptor blocker; $\mathrm{BB}, \beta$-blocker; $\mathrm{Cl}$, confidence interval; TD, thiazide diuretic.

Parenthesis indicates number of patients.

aDifferences in the incidence of primary and secondary cardiovascular events, all-cause mortality and new-onset diabetes among the three groups and between patients $<65$ years old and patients $\geqslant 65$ years old were compared using Log-rank test.

Hyperuricemia, hyperkalemia and vertigo were more frequent in older patients than in younger patients. Furthermore, among both the older and younger groups, hyperuricemia and hypokalemia were more frequently reported in the benidipine-thiazide group. On the other hand, bradycardia was more frequent in the benidipine- $\beta$-blocker group compared with the other benidipine-based combinations in both older and younger patients. Alanine aminotranferase increase was more frequently reported in the benidipine-thiazide group than in the other treatment groups and only in younger patients. Hyperkalemia was more frequent only in the benidipine-ARB group of the older group. There were no significant differences among the three benidi- pine-based regimens concerning serious adverse events either in older or younger patients (Supplementary data).

\section{DISCUSSION}

Aging is associated with a progressive increase in aortic stiffness, and the majority of elderly people have isolated systolic hypertension. ${ }^{8}$ This was consistently observed in patients $\geqslant 65$ years old in the COPE trial. The main effect of CCBs is dilatation of coronary and peripheral arteries, indicating that CCBs are well suited for elderly patients whose hypertensive profile is potentially multiple organ damage, and are well tolerated by the elderly. ${ }^{9,10}$ 
(\%)

Patients $<65$ years old

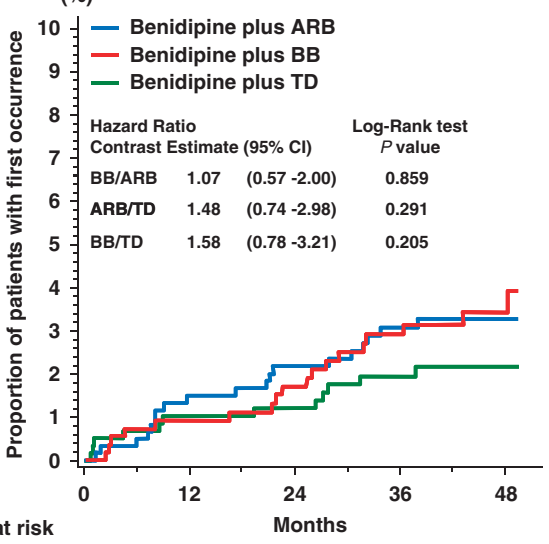

Number at risk

$\begin{array}{llllllllll}\text { Benidipine plus ARB } & 612 & 600 & 586 & 575 & 561 & 546 & 534 & 356 & 181\end{array}$

$\begin{array}{llllllllll}\text { Benidipine plus BB } & 555 & 543 & 516 & 505 & 492 & 478 & 460 & 320 & 164\end{array}$ $\begin{array}{lllllllllll}\text { Benidipine plus TD } & 593 & 577 & 558 & 547 & 540 & 529 & 515 & 348 & 181\end{array}$

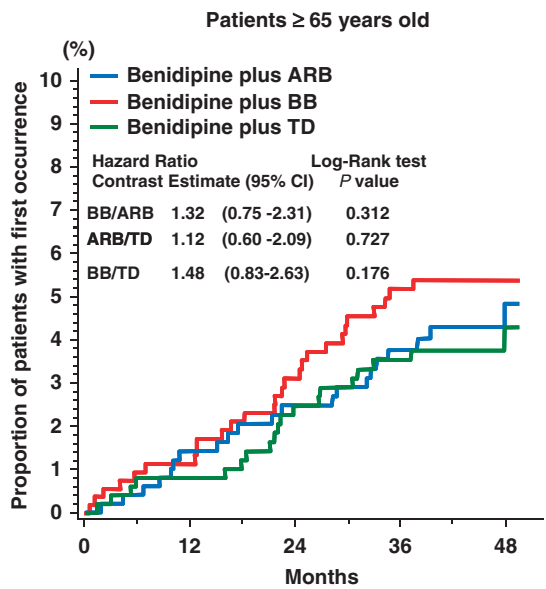

$\begin{array}{lllllllll}498 & 496 & 476 & 466 & 459 & 449 & 436 & 278 & 141\end{array}$

$\begin{array}{lllllllll}534 & 520 & 506 & 490 & 476 & 457 & 446 & 283 & 144\end{array}$ $\begin{array}{lllllllll}501 & 492 & 483 & 475 & 462 & 455 & 437 & 272 & 143\end{array}$

Figure 1 Kaplan-Meier curves for time to first primary cardiovascular composite end point in the two age groups and three treatment groups. ARB, angiotensin receptor blocker; $\mathrm{BB}, \beta$-blocker; $\mathrm{Cl}$, confidence interval; TD, thiazide diuretic.

\begin{tabular}{|c|c|c|c|c|c|c|c|c|}
\hline \multirow{2}{*}{ Contrast } & \multicolumn{3}{|c|}{ Patients $<65$ years old } & \multicolumn{4}{|c|}{ Patients $\geq 65$ years old } & \multirow{2}{*}{$\begin{array}{c}\text { Heterogeneity } \\
\text { P value }\end{array}$} \\
\hline & Hazard R & tio $(95 \% \mathrm{Cl})$ & $\begin{array}{l}\text { Log-Rank } \\
\text { P value }\end{array}$ & & Hazard & Ratio $(95 \% \mathrm{Cl})$ & $\begin{array}{l}\text { Log-Rank } \\
\text { P value }\end{array}$ & \\
\hline \multicolumn{9}{|l|}{ Primary Endpoints } \\
\hline Benidipine plus BB vs. Benidipine plus ARB & 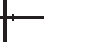 & $1.07(0.57-2.00)$ & 0.859 & & & $1.32(0.75-2.31)$ & 0.312 & 0.639 \\
\hline Benidipine plus ARB vs. Benidipine plus TD & & $1.48(0.74-2.98)$ & 0.291 & & & $1.12(0.60-2.09)$ & 0.727 & 0.560 \\
\hline Benidipine plus BB vs. Benidipine plus TD & & $1.58(0.78-3.21)$ & 0.205 & & + & $1.48(0.83-2.63)$ & 0.176 & 0.870 \\
\hline \multicolumn{9}{|l|}{ Cardiovascular Hard Endpoints } \\
\hline Benidipine plus BB vs. Benidipine plus ARB & & $1.03(0.46-2.34)$ & 0.989 & & & $1.31(0.64-2.68)$ & 0.416 & 0.670 \\
\hline Benidipine plus ARB vs. Benidipine plus TD & & $2.88(0.93-8.93)$ & 0.077 & & & $1.33(0.58-3.03)$ & 0.528 & 0.274 \\
\hline Benidipine plus BB vs. Benidipine plus TD & & $2.97(0.95-9.33)$ & 0.067 & & & $1.74(0.80-3.77)$ & 0.153 & 0.438 \\
\hline \multicolumn{9}{|l|}{ Fatal and Non-fatal Stroke } \\
\hline Benidipine plus BB vs. Benidipine plus ARB & & $1.41(0.56-3.58)$ & 0.454 & & & $1.79(0.80-4.01)$ & 0.109 & 0.709 \\
\hline Benidipine plus BB vs. Benidipine plus TD & & $1.80(0.66-4.96)$ & 0.242 & & & $2.74(1.08-6.96)$ & 0.022 & 0.557 \\
\hline \multicolumn{9}{|l|}{ All-cause Mortality } \\
\hline Benidipine plus BB vs. Benidipine plus ARB & - & $0.46(0.09-2.35)$ & 0.454 & & - & $0.99(0.54-1.82)$ & 0.983 & 0.384 \\
\hline Benidipine plus ARB vs. Benidipine plus TD & - & $0.60(0.20-1.82)$ & 0.312 & & & $1.36(0.69-2.65)$ & 0.382 & 0.217 \\
\hline Benidipine plus BB vs. Benidipine plus TD & & $0.27(0.06-1.28)$ & 0.071 & & & $1.34(0.69-2.60)$ & 0.400 & 0.063 \\
\hline \multicolumn{9}{|l|}{ New-onset Diabetes } \\
\hline Benidipine plus BB vs. Benidipineplus ARB & & $1.54(0.77-3.08)$ & 0.215 & & & $2.47(1.03-5.91)$ & 0.043 & 0.408 \\
\hline Benidipine plus ARB vs. Benidipine plus TD & & $0.78(0.39-1.59)$ & 0.505 & & & $0.47(0.19-1.15)$ & 0.121 & 0.379 \\
\hline Benidipine plus BB vs. Benidipine plus TD & - & $1.21(0.63-2.32)$ & 0.570 & & & $1.16(0.58-2.29)$ & 0.630 & 0.930 \\
\hline \multicolumn{9}{|c|}{ 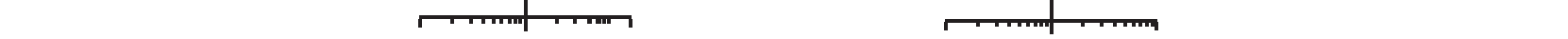 } \\
\hline \multicolumn{9}{|c|}{$\begin{array}{c}1 \\
\text { Hazard Ratio }\end{array}$} \\
\hline $\begin{array}{l}\text { Benidipine plus BB } \\
\text { Benidipine plus ARB } \\
\text { Benidipine plus BB }\end{array}$ & $\begin{array}{l}\rightarrow \text { Benidip } \\
\rightarrow \text { Benidip } \\
\rightarrow \text { Benidip }\end{array}$ & $\begin{array}{l}\text { ine plus ARB better } \\
\text { ine plus TD better } \\
\text { ine plus TD better }\end{array}$ & $\begin{array}{r}\text { Benidipin } \\
\text { Benidipine } \\
\text { Benidipin }\end{array}$ & $\begin{array}{l}\text { lus BB better } \leftarrow \\
\text { us ARB better } \leftarrow \\
\text { olus BB better } \leftarrow\end{array}$ & $\begin{array}{l}\rightarrow \text { Benidi } \\
\rightarrow \text { Benidip } \\
\rightarrow \text { Benidi }\end{array}$ & $\begin{array}{l}\text { oine plus ARB better } \\
\text { oine plus TD better } \\
\text { oine plus TD better }\end{array}$ & & \\
\hline
\end{tabular}

Figure 2 Hazard ratios for primary cardiovascular composite end point and secondary end points: cardiovascular hard end points, fatal and non-fatal stroke, all-cause mortality and new-onset diabetes in the two age groups and three treatment groups. Cardiovascular hard composite end points consist of cardiovascular death, fatal or non-fatal myocardial infarction, and stroke excluding transient ischemic attack. ARB, angiotensin receptor blocker; BB, $\beta$ blocker; $\mathrm{Cl}$, confidence interval; TD, thiazide diuretic. 


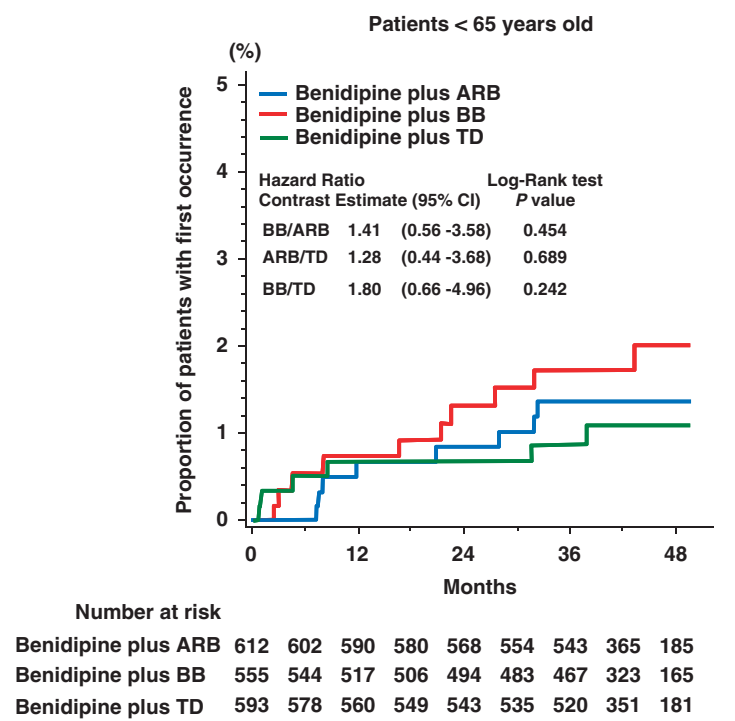

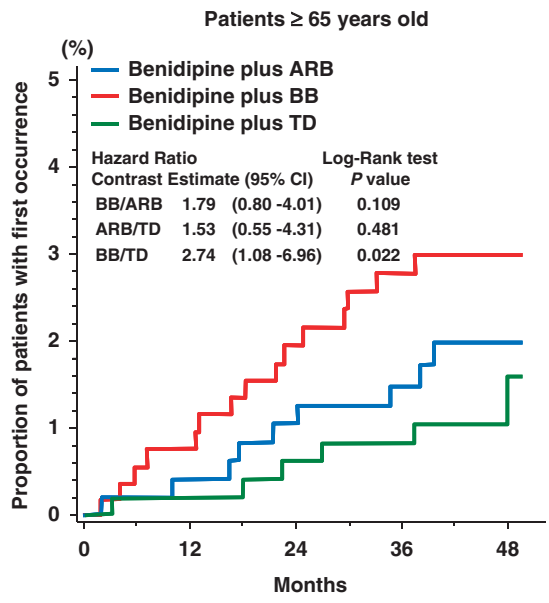

$\begin{array}{lllllllll}498 & 496 & 480 & 470 & 463 & 455 & 445 & 285 & 145\end{array}$ $\begin{array}{lllllllll}534 & 522 & 507 & 493 & 481 & 465 & 455 & 290 & 146\end{array}$ $\begin{array}{lllllllll}501 & 494 & 485 & 479 & 469 & 464 & 447 & 280 & 147\end{array}$

Figure 3 Kaplan-Meier curves for time to first fatal and non-fatal stroke in the two age groups and three treatment groups. ARB, angiotensin receptor blocker; $\mathrm{BB}, \beta$-blocker; $\mathrm{Cl}$, confidence interval; TD, thiazide diuretic.

Table 4 Adverse events

\begin{tabular}{|c|c|c|c|c|c|c|c|c|c|c|c|}
\hline & \multicolumn{5}{|c|}{ Patients $<65$ years old $(\mathrm{n}=1760)$} & \multicolumn{5}{|c|}{ Patients $\geqslant 65$ years old $(n=1533)$} & \multirow[b]{2}{*}{$\begin{array}{c}\text { Patients }<65 \text { years old } \\
\text { vs. } \geqslant 65 \text { years old } \\
\text { P value }\end{array}$} \\
\hline & $\begin{array}{c}\text { Benidipine } \\
\text { plus } A R B \\
(\mathrm{n}=612)\end{array}$ & $\begin{array}{l}\text { Benidipine } \\
\text { plus } B B \\
(\mathrm{n}=555)\end{array}$ & $\begin{array}{l}\text { Benidipine } \\
\text { plus TD } \\
(\mathrm{n}=593)\end{array}$ & P value & Total & $\begin{array}{c}\text { Benidipine } \\
\text { plus ARB } \\
(\mathrm{n}=498)\end{array}$ & $\begin{array}{l}\text { Benidipine } \\
\text { plus } B B \\
(\mathrm{n}=534)\end{array}$ & $\begin{array}{l}\text { Benidipine } \\
\text { plus TD } \\
(\mathrm{n}=501)\end{array}$ & P value & Total & \\
\hline \multicolumn{12}{|c|}{ Common adverse events in the COPE tria/ } \\
\hline Hyperuricemia & $15(2.5)$ & $13(2.3)$ & $53(8.9)$ & $<0.001$ & $81(4.6)$ & $8(1.6)$ & $9(1.7)$ & $26(5.2)$ & $<0.001$ & $43(2.8)$ & 0.007 \\
\hline Blood creatinine increased & $5(0.8)$ & $2(0.4)$ & $8(1.3)$ & 0.189 & $15(0.9)$ & $4(0.8)$ & $4(0.7)$ & $11(2.2)$ & 0.062 & 19 (1.2) & 0.273 \\
\hline ALT increased & $17(2.8)$ & $9(1.6)$ & $28(4.7)$ & 0.008 & $54(3.1)$ & $15(3.0)$ & $6(1.1)$ & $10(2.0)$ & 0.098 & $31(2.0)$ & 0.059 \\
\hline Vertigo & $4(0.7)$ & $3(0.5)$ & $7(1.2)$ & 0.422 & $14(0.8)$ & $2(0.4)$ & $17(3.2)$ & $10(2.0)$ & 0.005 & $29(1.9)$ & 0.006 \\
\hline Bradycardia & $3(0.5)$ & $21(3.8)$ & $1(0.2)$ & $<0.001$ & $25(1.4)$ & $0(0.0)$ & $27(5.1)$ & $0(0.0)$ & $<0.001$ & $27(1.8)$ & 0.434 \\
\hline Overall & 261 (42.6) & 231 (41.6) & $267(45.0)$ & 0.486 & 759 (43.1) & 244 (49.0) & 264 (49.4) & 255 & 0.820 & 763 (49.8) & $<0.001$ \\
\hline
\end{tabular}

Abbreviations: ARB, angiotensin receptor blocker; ALT, alanine aminotransferase; BB, $\beta$-blocker; TD, thiazide diuretic. Data are shown as number of patients (\%).

aAdverse events shown in the Table were previously reported. ${ }^{7}$

The Japanese Trial to Assess Optimal Systolic Blood Pressure in Elderly Hypertensive Patients (JATOS) compared the 2-year effect of strict treatment to maintain systolic BP $<140 \mathrm{~mm} \mathrm{Hg}$ with that of mild treatment to maintain systolic BP $<160$ but $\geqslant 140 \mathrm{~mm} \mathrm{Hg}$ in elderly hypertensive patients with a long-acting $\mathrm{CCB}$, efonidipine hydrochloride. ${ }^{11}$ This study demonstrated that the incidence of the primary combined end point (the incidence of cardiovascular disease and renal failure) was similar in the two groups, suggesting that complex clinical features were associated with aging. ${ }^{11}$ The Japan's Benidipine Research on Antihypertensive Effects in the Elderly (JBRAVE), which was an observational study of benidipine-based treatment in hypertensive patients $\geqslant 65$ years old, showed that ontreatment, systolic BP $\geqslant 160 \mathrm{~mm} \mathrm{Hg}$ was associated with a higher incidence of cardiovascular events, ${ }^{12}$ suggesting that even in older hypertensive patients, systolic BP should be lower than at least $160 \mathrm{~mm} \mathrm{Hg} .{ }^{13}$ In the COPE trial, the percentage of patients who achieved the target BP was higher than in the J-BRAVE study, and the incidence of cardiovascular events was lower, indicating that especially in older hypertensive patients, strict BP control is necessary to reduce cardiovascular events.

Most elderly persons will need more than two drugs to control their hypertension. ${ }^{14}$ The Japanese Society of Hypertension Guidelines for the Management of Hypertension (JSH 2009) recommend to introduce combination therapy as the initial treatment for grade II $\left(\geqslant 160 / 100 \mathrm{~mm} \mathrm{Hg}\right.$ ) hypertension. ${ }^{2}$ And the 2009 Updated European Society of Hypertension (ESH) guidelines also state that if $\mathrm{BP}$ is $>20$ / $10 \mathrm{~mm} \mathrm{Hg}$ above $<140 / 90 \mathrm{~mm} \mathrm{Hg}$, consideration should be given for starting with two drugs. ${ }^{15}$ The JSH 2009 guidelines recommend the addition of diuretics, ARB, angiotensin-converting enzyme inhibitor, and $\beta$-blockers to $\mathrm{CCB}$ for hypertensive patients; besides $\mathrm{CCB}$ combined with $\mathrm{ARB}$, angiotensin-converting enzyme inhibitor or diuretics, and diuretics combined with $\mathrm{ARB}$ or angiotensin-converting enzyme inhibitor are recommended as combination therapy for elderly hypertension. ${ }^{2}$ In addition, the American Society of 
Hypertension (ASH) has listed $\mathrm{CCB}$ with $\mathrm{ARB}$ as the preferred combination therapy, and $\mathrm{CCB}$ with diuretics as an acceptable combination therapy. ${ }^{16}$ These recommended combinations are expected to increase antihypertensive efficacy and to reduce adverse events; however, these are not proved by outcome studies. The findings of the COPE trial showed that benidipine-based thiazide, $\mathrm{ARB}$ and $\beta$-blocker therapy are equally effective in preventing the cardiovascular events in both older ( $\geqslant 65$ years old) and younger patients $(<65$ years old).

Isolated systolic hypertension is an important component of BPrelated stroke risk. ${ }^{17} \mathrm{~A}$ meta-analysis demonstrated that preventive effects against coronary heart disease were similar in different class-drugs, whereas $\beta$-blockers were worse in preventing stroke than the other classes of antihypertensive drugs including CCBs. ${ }^{18}$ Furthermore, a recent study has shown that interindividual variation in systolic BP was significantly reduced by CCBs and non-loop diuretic drugs, but significantly increased by angiotensin-converting enzyme inhibitors, ARB and $\beta$-blockers; thus, the difference in the reduction of the risk of stroke was independent of the effects on mean systolic BP. ${ }^{19}$ These results may support the results of the COPE trial, which demonstrated that the benidipine-thiazide combination reduced the risk of stroke more effectively than the benidipine- $\beta$ blocker regimen in hypertensive patients, particularly those who were $\geqslant 65$ years old.

Although the strength of the association between BP level and stroke decreased with age, the benefit of antihypertensive treatment might be important concerning the risk of stroke in the elderly. ${ }^{20}$ However, the benefit of $\mathrm{BP}$ reduction regarding the risk of stroke was demonstrated in elderly patients treated for hypertension with thiazide-based therapy. ${ }^{4,21-26}$ Furthermore, late elderly hypertensive patients ( $\geqslant 80$ years old) showed a $30 \%$ reduction of the risk of stroke in association with the reduction of all-cause mortality during indapamide-based treatment. ${ }^{4}$ It is also reported that CCBs favor the prevention of stroke compared with regimens based on diuretics or $\beta$ blockers. ${ }^{27,28}$ In addition, the risk of stroke decreases in relation to BP reduction rather than to a specific class of drugs. ${ }^{29,30}$ Furthermore, a meta-analysis showed no difference between younger ( $<65$ years old) and older patients ( $\geqslant 65$ years old) in protection against major vascular events provided by major drug classes. ${ }^{30}$ In the COPE trial, we observed a greater effect regarding the prevention of stroke in the benidipine-thiazide group as compared with the $\beta$-blocker group of the older group despite a similar reduction in BP among the three treatment groups. These results indicated that the benidipine-thiazide combination may be beneficial in patients $\geqslant 65$ years old, and these results together with those of the COPE trial may support the recommendation of the $\mathrm{JSH} 2009$ guidelines for the treatment of hypertension in the elderly. ${ }^{2}$

\section{Study limitations}

First, we adopted the PROBE design, so that non-blinded treatment allocation could have influenced the attitude of patients and investigators toward compliance with the study medications or staying in the study. Second, because the sample size of this sub-analysis was relatively small, the optimal combination therapy for elderly hypertensive patients should be investigated in a future trial. Third, we randomly assigned one of the three classes of antihypertensive agents without any restriction regarding the drugs in each class. Although there were no significant differences in event rates among the three treatment groups between older and younger hypertensive patients, we cannot deduce that the present results were caused by drug class effects, especially in the case of $\beta$-blockers. Finally, due to the inherent limitations of any study such as this trial, the finding that a CCB combined with a $\beta$-blocker was inferior in terms of incidence of stroke and new-onset diabetes in hypertensive patients $\geqslant 65$ years old should be confirmed or refuted by future studies.

In conclusion, $\mathrm{CCB}$ combined with an $\mathrm{ARB}$, a $\beta$-blocker or a thiazide diuretic was similarly effective regarding prevention of cardiovascular events and achievement of the target BP in hypertensive patients $<65$ years old and those $\geqslant 65$ years old who did not reach the target BP with $4 \mathrm{mg}$ per day of benidipine. However, the incidence of fatal and non-fatal stroke was significantly higher, and new-onset diabetes was found more frequently in patients treated with CCB and a $\beta$-blocker than in those treated with the other combinations, especially in hypertensive patients $\geqslant 65$ years. On the basis of the results of this sub-analysis, it is possible to conclude that CCB combined with diuretics or an ARB is a useful treatment for hypertensive patients $\geqslant 65$ years old.

\section{CONFLICT OF INTEREST}

All the authors report receiving lecture fees from various pharmaceutical companies in Japan, including Kyowa Hakko Kirin Co., Ltd., Japan.

\section{ACKNOWLEDGEMENTS}

We thank the collaborators and members of the COPE trial group. The present trial was conducted as a collaborative research between Yamaguchi University and the sponsor (Kyowa Hakko Kirin Co., Ltd.). This study was supported by the Japanese Society of Hypertension.

1 Mancia G, De Backer G, Dominiczak A, Cifkova R, Fagard R, Germano G, Grassi G, Heagerty AM, Kjeldsen SE, Laurent S, Narkiewicz K, Ruilope L, Rynkiewicz A, Schmieder RE, Boudier HA, Zanchetti A, Vahanian A, Camm J, De Caterina R, Dean V, Dickstein K, Filippatos G, Funck-Brentano C, Hellemans I, Kristensen SD, McGregor K, Sechtem U, Silber S, Tendera M, Widimsky P, Zamorano JL, Erdine S, Kiowski W, Agabiti-Rosei E, Ambrosioni E, Lindholm LH, Viigimaa M, Adamopoulos S, Bertomeu V, Clement D, Farsang C, Gaita D, Lip G, Mallion JM, Manolis AJ, Nilsson PM, O'Brien E, Ponikowski P, Redon J, Ruschitzka F, Tamargo J, van Zwieten P, Waeber B, Williams B. 2007 guidelines for the management of arterial hypertension: the task force for the management of arterial hypertension of the European Society of Hypertension (ESH) and of the European Society of Cardiology (ESC). J Hypertens 2007; 25: 1105-1187.

2 Ogihara T, Kikuchi K, Matsuoka H, Fujita T, Higaki J, Horiuchi M, Imai Y, Imaizumi T, Ito S, Iwao H, Kario K, Kawano Y, Kim-Mitsuyama S, Kimura G, Matsubara H, Matsuura H, Naruse M, Saito I, Shimada K, Shimamoto K, Suzuki H, Takishita S, Tanahashi N, Tsuchihashi T, Uchiyama M, Ueda S, Ueshima H, Umemura S, Ishimitsu T, Rakugi H. The Japanese Society of Hypertension Guidelines for the Management of Hypertension (JSH 2009). Hypertens Res 2009; 32: 3-107.

3 Chobanian AV, Bakris GL, Black HR, Cushman WC, Green LA, Izzo Jr JL, Jones DW, Materson BJ, Oparil S, Wright Jr JT, Roccella EJ. The seventh report of the joint national committee on prevention, detection, evaluation, and treatment of high blood pressure: the JNC 7 report. JAMA 2003; 289: 2560-2572.

4 Beckett NS, Peters R, Fletcher AE, Staessen JA, Liu L, Dumitrascu D, Stoyanovsky V, Antikainen RL, Nikitin Y, Anderson C, Belhani A, Forette F, Rajkumar C, Thijs L, Banya $\mathrm{W}$, Bulpitt CJ. Treatment of hypertension in patients 80 years of age or older. N Engl J Med 2008; 358: 1887-1898.

5 Yao K, Nagashima K, Miki H. Pharmacological, pharmacokinetic, and clinical properties of benidipine hydrochloride, a novel, long-acting calcium channel blocker. J Pharmacol Sci 2006; 100: 243-261.

6 Ogihara T, Matsuzaki M, Matsuoka H, Shimamoto K, Shimada K, Rakugi H, Umemoto S, Kamiya A, Suzuki N, Kumagai H, Ohashi Y, Takishita S, Abe K, Saruta T. The combination therapy of hypertension to prevent cardiovascular events (COPE) trial: rationale and design. Hypertens Res 2005; 28: 331-338.

7 Matsuzaki M, Ogihara T, Umemoto S, Rakugi H, Matsuoka H, Shimada K, Abe K, Suzuki N, Eto T, Higaki J, Ito S, Kamiya A, Kikuchi K, Suzuki H, Tei C, Ohashi Y, Saruta T. Prevention of cardiovascular events with calcium channel blocker-based combination therapies in patients with hypertension: a randomized controlled trial. J Hypertens 2011; 29: 1649-1659.

8 Franklin SS, Gustin 4th Wt, Wong ND, Larson MG, Weber MA, Kannel WB, Levy D. Hemodynamic patterns of age-related changes in blood pressure. The Framingham Heart Study. Circulation 1997; 96: 308-315. 
9 Abernethy DR, Schwartz JB, Todd EL, Luchi R, Snow E. Verapamil pharmacodynamics and disposition in young and elderly hypertensive patients. Altered electrocardiographic and hypotensive responses. Ann Intern Med 1986; 105: 329-336.

10 Pepine CJ, Handberg EM, Cooper-DeHoff RM, Marks RG, Kowey P, Messerli FH, Mancia G, Cangiano JL, Garcia-Barreto D, Keltai M, Erdine S, Bristol HA, Kolb HR, Bakris GL, Cohen JD, Parmley WW. A calcium antagonist vs a non-calcium antagonist hypertension treatment strategy for patients with coronary artery disease. The International Verapamil-Trandolapril Study (INVEST): a randomized controlled trial. JAMA 2003; 290: 2805-2816.

11 JATOS Study Group. Principal results of the Japanese trial to assess optimal systolic blood pressure in elderly hypertensive patients (JATOS). Hypertens Res 2008; 31: 2115-2127.

12 Saito I, Suzuki H, Kageyama S, Saruta T. Effect of antihypertensive treatment on cardiovascular events in elderly hypertensive patients: Japan's Benidipine Research on Antihypertensive Effects in the Elderly (J-BRAVE). Clin Exp Hypertens 2011; 33: 133-140.

13 Wang JG, Staessen JA. Benefits of antihypertensive drug treatment in elderly patients with isolated systolic hypertension. Neth J Med 2001; 58: 248-254.

14 Bakris GL. Maximizing cardiorenal benefit in the management of hypertension: achieve blood pressure goals. J Clin Hypertens 1999; 1: 141-147.

15 Mancia G, Laurent S, Agabiti-Rosei E, Ambrosioni E, Burnier M, Caulfield MJ, Cifkova R, Clement D, Coca A, Dominiczak A, Erdine S, Fagard R, Farsang C, Grassi G, Haller $H$, Heagerty A, Kjeldsen SE, Kiowski W, Mallion JM, Manolis A, Narkiewicz K, Nilsson $\mathrm{P}$, Olsen MH, Rahn KH, Redon J, Rodicio J, Ruilope L, Schmieder RE, Struijker-Boudier HA, Van Zwieten PA, Viigimaa M, Zanchetti A. Reappraisal of European guidelines on hypertension management: a European Society of hypertension task force document. Blood Press 2009; 18: 308-347.

16 Gradman AH, Basile JN, Carter BL, Bakris GL. Combination therapy in hypertension. J Am Soc Hypertens 2010; 4: 42-50.

17 Kannel WB, Dawber TR, Sorlie P, Wolf PA. Components of blood pressure and risk of atherothrombotic brain infarction: the Framingham study. Stroke 1976; 7: 327-331.

18 Law MR, Morris JK, Wald NJ. Use of blood pressure lowering drugs in the prevention of cardiovascular disease: meta-analysis of 147 randomised trials in the context of expectations from prospective epidemiological studies. BMJ 2009; 338: b1665.

19 Webb AJ, Fischer U, Mehta Z, Rothwell PM. Effects of antihypertensive-drug class on interindividual variation in blood pressure and risk of stroke: a systematic review and meta-analysis. Lancet 2010; 375: 906-915.

20 Lewington S, Clarke R, Qizilbash N, Peto R, Collins R. Age-specific relevance of usual blood pressure to vascular mortality: a meta-analysis of individual data for one million adults in 61 prospective studies. Lancet 2002; 360: 1903-1913.
21 SHEP Cooperative Research Group. Prevention of stroke by antihypertensive drug treatment in older persons with isolated systolic hypertension. Final results of the Systolic Hypertension in the Elderly Program (SHEP). SHEP Cooperative Research Group. JAMA 1991; 265: 3255-3264.

22 Amery A, Birkenhager W, Brixko P, Bulpitt C, Clement D, Deruyttere M, De Schaepdryver A, Dollery C, Fagard R, Forette F, Forte J, Hamdy R, Henry JF, Joossens JV, Leonetti G, Lund-Johansen P, O'Malley K, Petrie J, Strasser T, Tuomilehto J, Williams B. Mortality and morbidity results from the European Working Party on High Blood Pressure in the Elderly trial. Lancet 1985; 1: 1349-1354.

23 MRC Working Party. Medical Research Council trial of treatment of hypertension in older adults: principal results. MRC Working Party. BMJ 1992; 304: 405-412.

24 Dahlof B, Lindholm LH, Hansson L, Schersten B, Ekbom T, Wester PO. Morbidity and mortality in the Swedish Trial in Old Patients with Hypertension (STOP-Hypertension). Lancet 1991; 338: 1281-1285.

25 Patel AB, Kostis JB, Wilson AC, Shea ML, Pressel SL, Davis BR. Long-term fatal outcomes in subjects with stroke or transient ischemic attack: fourteenyear follow-up of the systolic hypertension in the elderly program. Stroke 2008; 39: 1084-1089

26 Liu L, Wang Z, Gong L, Zhang Y, Thijs L, Staessen JA, Wang J. Blood pressure reduction for the secondary prevention of stroke: a Chinese trial and a systematic review of the literature. Hypertens Res 2009; 32: 1032-1040.

27 Collier DJ, Poulter NR, Dahlof B, Sever PS, Wedel H, Buch J, Caulfield MJ. Impact of amlodipine-based therapy among older and younger patients in the Anglo-Scandinavian Cardiac Outcomes Trial-Blood Pressure Lowering Arm (ASCOT-BPLA). J Hypertens 2011; 29: 583-591.

28 Turnbull F. Effects of different blood-pressure-lowering regimens on major cardiovascular events: results of prospectively-designed overviews of randomised trials. Lancet 2003; 362: 1527-1535.

29 ALLHAT Officers and Coordinators for the ALLHAT Collaborative Research Group; The Antihypertensive and Lipid-Lowering Treatment to Prevent Heart Attack Trial. Major outcomes in high-risk hypertensive patients randomized to angiotensin-converting enzyme inhibitor or calcium channel blocker vs diuretic: The Antihypertensive and Lipid-Lowering Treatment to Prevent Heart Attack Trial (ALLHAT). JAMA 2002; 288: 2981-2997.

30 Blood Pressure Lowering Treatment Trialists' Collaboration, Turnbull F, Neal B, Ninomiya T, Algert C, Arima H, Barzi F, Bulpitt C, Chalmers J, Fagard R, Gleason A, Heritier S, Li N, Perkovic V, Woodward M, MacMahon S. Effects of different regimens to lower blood pressure on major cardiovascular events in older and younger adults: metaanalysis of randomised trials. BMJ 2008; 336: 1121-1123.

Supplementary Information accompanies the paper on Hypertension Research website (http://www.nature.com/hr) 